New Zealand journal of industrial relations, $1988,13,257-275$

\title{
The origins and development of the personal grievance jurisdiction in New Zealand
}

\author{
Gordon Anderson *
}

This paper discusses the background to the personal grievance procedure introduced in the Industrial Relations Act 1973 and the implementation of the procedure up to the time of the reform of the law in 1987. The central role of the Arbitration Court in developing the minimal legislative framework of the law is stressed. The paper concludes with a discussion of the debate leading up to the reforms and an evaluation of the effectiveness of the procedure at that point.

\section{Introduction}

The first legislative steps towards the establishment of a modern scheme of employment security law in New Zealand began with the passage of the Industrial Conciliation and Arbitration Amendment Act 1970. In this area New Zealand had begun to lag significantly behind the countries in Western Europe which had, in the main, introduced legislation during the post-war period. ${ }^{1}$ The United Kingdom, however, did not act until the enactment of the unfair dismissal procedures in the Industrial Relations Act 1971. While the reasons for the initiative to introduce legislation in New Zealand seems to have largely reflected domestic political concerns, at the same time there was an increasing awareness of the defects in the existing system and of international developments in the area of employment security which gave a broader justification for the political moves.

This paper will briefly discuss the background to the 1970 legislation and then consider the nature of the personal grievance procedure that was introduced in 1973. The major part of the paper will concentrate on the development of the law by the Arbitration Court ${ }^{2}$ between 1973 and the time of the review of the legislation as part of the Green paper debate in 1985-86. The paper will conclude with a summary of the main points raised in the submissions to the Green Paper.

1 e.g. In 1965 legislative protection existed in Austria, Belgium, Denmark, France, Italy, Netherlands, Spain, Sweden, and West Germany. 


\section{Employment security}

Although this paper is concerned primarily with one aspect of employment security, dismissal, it should be emphasised that this is only one aspect of the general problem of employment security. Genuine employment security involves a much wider range of issues such as non-discriminatory access to employment opportunities and equal opportunities for advancement within employment as well as protection against the worst of the economic consequences of loss of employment. These aspects of employment security had never really been addressed by the common law, although there were indications of the beginning of some recognition of the problems involved. ${ }^{3}$ In practice the radical change in attitudes and in the law needed the backing of legislation to give the required degree of impetus. In New Zealand the legislative framework began to be constructed during the 1970s with the Race Relations Act 1971, the Human Rights Commission Act 1977 and the Equal Pay Act 1972. As the current debate on equal pay illustrates there is still some way to go before employment security in this broad sense can be said to have been achieved.

Although it is not possible to address all these issues within the context of this paper it should be emphasised that protection from unfair dismissal is of little use if opportunities to obtain employment or to advance within employment are arbitrarily restricted in the case of some groups of workers. This problem may be being overcome but it is by no means solved. Unfortunately there is a tendency to treat different areas of employment security as different issues rather than to regard them as a single if multifaceted problem.

While it may be obvious, it is worth restating that the great majority of workers rely exclusively on their employment to provide them with an income and an acceptable standard of living. Moreover most workers do not receive an income that is sufficently large to allow the accumulation of sufficent savings to tide them over significant periods of unemployment. In a modern capitalist economy a strong legal base for employment security is essential for the economic security of the great majority of workers.

It is for this reason that unjustifiable dismissal law must be seen as more than a problem of industrial relations or of how to solve a particular type of industrial dispute, attitudes that seemed to be at the heart of the original discussion in New Zealand and which are still a dominant theme. This is especially so where the worker is not a member of a strong union and must rely purely on their legal rights.

The power of an employer to dismiss a worker, for whatever reason, is an extremely powerful penal-disciplinary sanction that can result in a substantial economic penalty being imposed on the worker, a penalty that in some environments and economic conditions can lead to considerable periods of unemployment and consequent economic hardship for both the worker and their dependents. Even in less severe cases the worker will be likely to lose accumulated benefits such as seniority rights, accumulated service towards long-service leave and in some cases accumulated pension rights which can be a significant economic cost.

In practice these penalties can be imposed for what are seemingly trivial acts of "insubordination" or for trivial breaches of workplace discipline, and indeed at common law no reason at all was required. It is when one compares the potential penalty, penalties that would often be unacceptable for similiar offences in criminal law, in relation to the relative insignificance of the offence in many cases that the need for legal protection becomes clear. The law of employment security, and of dismissal in particular, should be evaluated by the extent to which it protects the economic security of the worker. 


\section{The ILO's standards on termination of employment}

The ILO's adoption of the Recommendation on Termination of Employment at the Initiative of the Employer (No 119) in 1963 provided a clear illustration of how the law in New Zealand had fallen behind internationally acceptable standards. In outline the ILO Recommendation provided that a worker's employment should not be terminated unless valid grounds connected with the conduct or capacity of the worker or the operational requirements of the undertaking existed. Additionally, it was specifically provided that some grounds were not to provide a justification for dismissal. These included union activities and general discrimination. ${ }^{4}$ Equally important was the Recommendation's second major requirement, that terminations were to be appealable to an impartial body with the power to decide the issue and to grant remedies including reinstatement where a termination was held to be unjustified. The ILO's commitment to employment security standards has been comfirmed by its consolidation and expansion of those standards since 1963. The present standards are Convention 158 and Recommendation 166 Concerning Termination of Employment at the Initiative of the Employer adopted in 1982.

While these new standards were generally supported they did meet with considerable opposition from some groups, especially United States and British employers. The United States employers in particular seemed concerned to protect the "at will" rule although they were also concerned to limit consultation on the issue of redundancies and in particular to prevent any investigation of the parent company's motives or decisions. This opposition resulted in some of the more innovative improvements in the draft instruments being deleted from the instruments finally adopted. For example, the suggestion that employment continue pending the resolution of a case ${ }^{5}$. The advance from recommendation to convention status did however stress the importance the ILO places on security of employment. The Convention was adopted with only one government dissent, the United States. The New Zealand Government and workers groups supported both instruments, the employers abstaining. The New Zealand Government has subsequently indicated that it will not ratify the Convention ${ }^{6}$.

\section{The origins of the New Zealand system}

Until 1970 a New Zealand worker who considered that they had been unjustifiably dismissed had two options: to seek support from their union or to resort to a common law action. The common law provided, and continues to provide, a stark contrast to the ILO's standards. At common law no effective remedy for an unjustified dismissal existed. The only constraint on an employer's ability to dismiss was the requirement that the employer give the period of notice provided in the contract of employment or, where there was no such period, a reasonable period of notice. Even the notice requirement could be avoided if payment in lieu of notice was made. An employer was under no obligation to give reasons for the dismissal or to justify any reasons that might be given. The worker's disadvantage was further compounded by the Addis rule which places severe restrictions on the damages that a dismissed worker can claim. Damages were in almost all cases limited to the amount that would have been paid had the required notice in fact been given, exception of political discrimination.

6 Appendix to the Journals of the House of Representatives (1983) Paper A7 pp. 33 35 . 
or given the duty to mitigate one's loss, the lesser actual wages lost during the proper notice period.

In practice the common law was unlikely to provide a remedy for any but highly paid workers ${ }^{7}$ even where its restrictive conditions were met. The short periods of notice provided in most awards, and thus the low level of possible damages, made an action at common law uneconomic in the majority of cases. The average worker was of neccesity forced to rely on the benign nature of their employer or on the strength of their union organisation if they were to receive a measure of economic security in their life.

Since the 1970 s the common law has not changed and for those workers outside the scope of the personal grievance procedure there continues to be little legal protection. Not only has the common law not changed, it seems to have resolutely set its face against reform. Several cases over the last few years have seen a refusal to modify either the basic premises of liability or the Addis rule, even in cases where it has worked considerable injustice, ${ }^{8}$ and the basic premise that a dismissal need not be justified remains intact. Any significant change in the law obviously requires legislative intervention.

In $1966 \mathrm{Mr}$ R Green published a paper, Procedures to settle disputes over alleged wrongful dismissal (Green, 1966), in which he discussed the response of employers and unions to an initiative of the then Minister of Labour to have adopted a standard procedure to deal with alleged wrongful dismissals. Such a procedure had been advocated in the National Party's election manifesto in 1963 and a suggested procedure was proposed by the Minister the next year. Green summarised the reactions as "unfavourable". The reasons advanced by the two sides were partly as one would predict; the employers saw a restriction on their "right" to hire and fire and some unions at least prefered the "show of force" approach. The other reasons given were often more interesting; there was for example a shared mistrust of the ability of some conciliation commissioners to deal with such grievances and a preference for existing informal procedures. Some union officials also contended that workers would abuse the system with unmeritorious complaints. Unionists were also concerned that compensation rather than reinstatement would become the norm. These responses probably retain some validity today, although one reason that employers gave, that in a time of full employment such procedures are not needed, would certainly be somewhat inappropriate in modern conditions.

Although the response in 1964-65 may have been lukewarm, legislation to establish a personal grievance procedure was introduced in 1970. The 1970 legislation provided for a voluntary procedure to settle disputes over "wrongful dismissals", a wording that effectively neutered the procedure in that it confined the procedure to dismissals that were unlawful at common law. This result does not seem to have been intended by the employers' organisations ${ }^{9}$, but the government itself seemed quite aware of what it was doing. During the debate on the Bill the Minister stated in response to criticism of the term "wrongful dismisal" that any wider provision:

would in fact remove the right of the employer to hire and fire .... If we added the words 'or unfairly' it would open up the whole range of dismissals whether they were lawful or not. 10

e.g North Island Wholesale Groceries Ltd v Hewin [1982] 2 NZLR 176.

8 See for example Gee v Timaru Milling Co Ltd (1986) unreported, High Court A387/85 and more generally Vivian v Coca Cola Export Corporation [1984] 2 NZLR 289. The Court of Appeal has recently indicated that the Addis rule requires reconsideration; Hetherington v Faudet (1988) unreported CA 37/88.

9 See the comments of the Employers' Federation in submissions on the 1973 Industrial Relations Bill.

10 New Zealand Parliamentary Debates, Volume 369 p. 4072. 
One of the most significant aspects of the 1970 legislation, and thus an aspect that lies at the base of the present procedure is that the Act seems, from the debates, to have had little to do with individual employment security and was seemingly a response to a political concern with an increasing number of strikes, many of which were attributed to dismissal disputes. Again this seems to have been made clear by the Minister who did not mention employment security or the ILO standards during his introductory speech, but did state that the Bill would provide:

a standard procedure for the settlement of personal grievances. These matters, particulary alleged wrongful dismissals, are a constant source of industrial disputes leading towards stoppages. About 11 percent of stoppages are caused by this type of grievance. 11

The introduction of an effective procedure had to wait another three years until the passage of section 117 of the Industrial Relations Act 1973. It is this procedure that, with minor modifications, lasted until 1987 and which is still the core of the present procedure.

\section{The 1973 personal grievance procedure}

The Industrial Relations Act 1973 required all awards and agreements to contain a procedure for the settlement of personal grievances and set out a standard procedure that was to apply in the absence of some other agreed procedure. In practice the standard procedure seems to have been almost universally adopted. ${ }^{12}$

\section{The standard procedure}

The standard procedure was quite straightforward and contained only three substantive steps (excluding the initial approach by the employee to the employer). These were:

(a) the union representative, "if he considered there was some substance" in the grievance took the grievance up with the employer;

(b) if not settled the grievance was referred to a grievance committee (of up to three representatives of each side) with or without a chairperson as the parties might decide;

(c) if not settled by the committee the grievance was referred to the Court for final settlement.

There was also the possibility of an appeal on a point of law only to the Court of Appeal under the general provisions of the Industrial Relations Act.

The legislative procedure thus envisaged the rapid settlement of grievances and discouraged appeals. A grievance only reached the Court if it was not "settled" at or before the committee stage, there being no right of appeal from a grievance committee. In practice most committees had a chairperson (usually a government employed mediator or conciliator) who could be empowered to make a decision so any "appeal" had to be anticipated by refusing the chairperson the power to make a binding decision.

Little concrete information is available on the first, informal, stage of the procedure but one point that does seem to emerge from anecdotal evidence is that if a union official, 
experienced in such matters, takes over the dispute at a very early stage a settlement may be reached before attitudes harden. It also seems that reinstatement is more likely at this stage.

Information on the workings of the committees is also sparse although some general features have been identified. The first is that while the grievance committee holds a semi-formal hearing of a grievance the emphasis seems to be on a negotiated or mediated settlement rather than an arbitrated decision by the chairperson. This seems to be supported by the outcome of grievances brought. In the year to 31 March 1985, (a reasonably "typical" year), the 658 grievances which reached the committee level were disposed of as follows: ${ }^{13}$

$\begin{array}{lrr}\text { Agreement by the parties } & 301 & (46 \%) \\ \text { Decision by chairperson } & 196 & (30 \%) \\ \text { Withdrawn } & 25 & (4 \%) \\ \text { Unsettled } & 136 & (20 \%)\end{array}$

Of the unsettled cases $95(14 \%)$ were referred to the Court.

A study of users of the mediation service by Howells and Cathro $(1986$, p. 100) indicated a strong preference for mediation, as opposed to arbitration, in resolving personal grievances and a report by a group of industrial relations practitioners remarked that at this stage "Often the proceedings focus on doing deals about the appropriate amount of compensation to the worker" (Long-Term Reform Committee, 1983 p. 27).

Although the majority of cases did not reach the Court, the Court nevertheless spent a considerable portion of its total time on dealing with unsettled personal grievance cases. By 1983, 21 percent of the total cases reaching the Court were personal grievance cases and they occupied 31 percent of hearing days. The time from filing to hearing also gradually increased and by 1983 the average delay had reached 22 weeks, up from 12 weeks in 1980.

\section{The scope of the procedure}

The procedure introduced in 1973 did not provide a universal remedy for all workers. Its scope was restricted to those workers who were union members and whose work was covered by an award or other agreement. ${ }^{14}$ These restrictions in practice operated to exclude a considerable number of workers. One only has to consider the relatively low maximum wage in the Clerical Workers' Award, above which award coverage ceases, to appreciate this. The need for award coverage also opened the possibility of technical defences related to award coverage. The Greenwich 15 case illustrated this point when workers, who were employed by an employment agency to solicit possible vacancies, were held to fall outside the industry description in the clerical award as only some 20 percent of their work was within the description.

The proviso as to union membership also caused some problems for the Court, in particular the issue of whether a worker needed to be a union member at the time of the grievance arising or whether they could join at a later point. After some initial confusion

13 All figures in this section are taken from Vol II of the Green Paper (Department of Labour 1985, pp. 165-167).

14 Auckland Freezing Works etc IUW v Te Kuiti Borough Council [1977] 1 NZLR 211.

15 [1980] ACJ 257. 
the Court reached the position that a worker joining after their dismissal was sufficent to give the union the right to initiate the grievance procedure ${ }^{16}$.

It should finally be noted in this context that the ILO standards do not seem to envisage protection for only limited groups of workers.

\section{The role of the worker's union}

Unlike similar procedures in most other countries the personal grievance procedure did not confer direct rights of access on individual workers. Instead, the procedure gave the worker's union the right to take a personal grievance action on behalf of the worker, their member. The decision as to whether or not to proceed with an action was also left to the union. Subsection 4 (c) of section 117 made this explicit when it said that the union need only proceed if there was "some substance" in the grievance. The union's power to decline to act was, however, constrained by the addition of sub-section $3 \mathrm{~A}$ in 1976, which allowed an individual worker direct access to the Court where their union failed to act or to act promptly in accordance with the procedure. The Court in considering applications for leave under subsection $3 \mathrm{~A}$ has supported the general position that a reasonable refusal to proceed by the union, even if unacceptable to the member ${ }^{17}$, will be grounds to refuse an application. The Court has however been reasonably liberal in admitting evidence as to the facts of the grievance to determine if in fact an applicant had a reasonable case. ${ }^{18}$

The decision to vest the right to use the procedure in the worker's union does leave some room for confusion as to the nature of the rights involved, and in particular whether there is a right to protection from unjustified dismissal (or other actions) granted to the individual worker or whether what is given is instead a collective right exercisable on the worker's behalf by their union. Szakats $(1988$, p. 308$)$ argues that the union's role is merely to pursue individual remedies on behalf of their members. This confusion probably results from the original purpose of the procedure, which was to prevent strikes, and from its inclusion in an Act that was concerned with collective labour relations. ${ }^{19}$ The vesting of the right to take action in the union is consistent with the overall policy of industrial relations legislation which, while it may confer benefits on individual workers, generally leaves enforcement to the workers union or other agency. In addition there was almost certainly the belief that the union would act as a filter of unmeritorious cases.

While the above point may seem somewhat academic and of limited practical significance, it is nevertheless important in that it raises a significant point of principle, that is whether workers should enjoy employment security protection in their own right and be able to pursue the right to such protection in their individual capacity. To require such rights to be controlled by and chanelled through a third party, particulary given the implication that claims need to be filtered by that third party, devalues the status of the right and of the individual worker. One must question whether an individual's most important economic asset, their employment, should be required to be protected by a third party. Employment protection still seems to be viewed as inferior to other legal rights that an individual may possess and is treated more as a privilege than as a concrete right. The "right" not to be unjustifiably dismissed is a statutory gloss on the contract of employment, it is not a term incorporated within that contract. (Townsend) v Brady (1986) ACJ 99. Cottage (1980) ACJ 61.

19 The extension of protection to all union members in 1987 does not help clarify this position. 
The above points should not however be seen as a criticism of the role that unions play in enforcing the right to employment security. A right that is in practice unenforcable because of cost, lack of expertise or for any other reason is worthless. It is the role of the union in operating the procedure on behalf of the individual worker that gives the present rights their effectiveness.

\section{The legislative structure and the role of the Court}

The legislative base of the personal grievance procedure, section 117 of the Industrial Relations Act 1973 was extremely short and straightfoward. A short definition of a "personal grievance" was set out and a three step procedure was established to settle disputes. This seemingly simple section resulted in a significant role for the Court, indeed it could be said that Parliament delegated much of its legislative function to the Court. The definition of a personal grievance in section 117 was deceptively simple. It provided that a personal grievance was:

any grievance that a worker may have against his employer because of a claim

(i) that he has been unjustifiably dismissed; or

(ii) that other action by the employer (not being action of a kind applicable generally to workers of the same class employed by the employer) affects his employment to his disadvantage ...

This seemingly simple definition left the Court to decide a number of quite complex issues as cases came before it. Even such basic questions as what was a "dismissal" were not defined and it was left to the Court to decide whether, for example, the term included a constructive dismissal. The Court was also required to develop a body of law on what conduct would justify a dismissal and whether it was legitimate to consider procedural aspects of the dismissal as well as the substantive in reaching a decision. In both cases no legislative guidelines were provided, an approach more in line with United States grievance procedures but which contrasts markedly with the approach in the United Kingdom where all these matters are defined in some detail. The substantive law governing personal grievances in New Zealand is thus almost entirely a creation of the Court and of the Court of Appeal, Parliament's role being confined to the creation of the basic jurisdiction.

In this paper it is obviously not possible, or indeed necessary, to consider the whole of the law as developed by the Courts ${ }^{20}$. Instead I will outline the more important areas that have developed as cases have come before the Court for decision. As will be seen from these developments, the Court has had to act in a reasonably innovative fashion to ensure that the procedure has operated with an adequate degree of effectiveness. The Court has, however, been able to rely on developments in other jurisdictions to aid it in its decisions, and indeed has acknowledged the range of sources it draws on in several cases.

In the Hepi ${ }^{21}$ case the Court outlined some of the factors that it takes into account in its decisions. At the general level these included;

good industrial relations practice, which includes some consideration of the social and moral attitudes of the community. The Court considers ILO

21 Wellington etc Drivers IUW v Fletcher Construction (1983) ACJ 653, p. 666. 
Recommendations and Conventions. The Court also has regard to its own earlier decisions and to the decisions of other Courts, both New Zealand and foreign.

The general approach to personal grievances, and to dismissals in particular, adopted by the Court has been endorsed by the Court of Appeal. The Court of Appeal's position was summarised by a statement in Hepi::

The Arbitration Court in New Zealand has put a benevolent construction upon section 117 both as to the circumstances which might be recognized as supporting a worker's grievance related to a claim of unjustified dismissal and also the point at which the grievance should be resolved in his favour. And taking into account that the Industrial Relations Act has the important purpose of improving industrial relations (as the long title makes plain). I would not wish in any way to derogate from that general approach .... Within reasonable limits the Arbitration Court ought to be left I think to develop its own methods and processes in order to find the fair and just solutions intended by the Act. ${ }^{22}$

The Court of Appeal also noted that the personal grievance procedure's function was the settlement of disputes and for this reason also a broad interpretation was justified.

The main issues of law that the Court has had to contend with or develop in summary have been:

\section{What is a dismissal ?}

In practice the most important aspect of the personal grievance procedure are allegations that a complainant has been "unjustifiably dismissed". The prerequisite for such an allegation is of course that there has been a dismissal. The question of whether or not there has been a dismissal can arise in at least three situations.

(a) At an early stage the Court decided that for a dismissal to occur the worker must have actually commenced work ${ }^{23}$. The personal grievance procedure thus protects a worker against dismissal from an existing job, not from breach of their contract of employment prior to work commencing.

(b) A dismissal will not occur where the contract of employment is terminated by mutual consent or by the expiry of a fixed term contract. These situations have however caused some problems. The most obvious is the factual issue as to whether a particular situation was a dismissal or a termination by agreement. This will often arise in cases of constructive dismissal (see below) but can occur in other situations ${ }^{24}$.

One particular problem, that arose in Auckland Hotel etc Employees' IUW v King Size Burgers Ltd ${ }^{25}$, is the situation where a worker has been given notice of dismissal but leaves the employment before the period of notice given has expired.

Wellington etc Drivers IUW v Fletcher Construction (1982) ACJ 663, p. 666 (Court of Appeal).

23 Auckland Clerical IUW v Wilson (1980) ACJ 357.

24 The area of fixed term and similiar contracts and the situation described in (a) are of concern in some unions. See the submission of Clerical Workers IAW on the Labour Relations Bill. 
In that case this was held by the Court to be either a mutual termination or an abandonment of employment by the worker, but not a dismissal. This approach is open to considerable criticism as it seems to equate dismissal with the end of work rather than the time the termination of the contract is effected (Anderson, 1982, p. 61). Once notice of dismissal has been given the term of the contract has essentially been determined and notice cannot be unilaterally revoked. The Court's decision puts a worker in the position of having to work out the notice given if they are to bring a claim for unjustified dismissal and thus avoid forfeiting what may be considerable compensation. These factors will additionally limit the ability to seek alternative employment. It is interesting to note that the United Kingdom legislation makes specific provision to safeguard the workers position in this type of situation ${ }^{26}$.

In the case of casual, temporary and similiar types of work the Court seems to have taken a pragmatic attitude that looks to the reality of the employment relationship as well as its strict legal form (Hughes, 1986, p. 9).

(c) Possibly the most significant development in developing the definition of a dismissal is the Court's acceptance of the concept of the constructive dismissal. This occurs in a situation where a worker resigns in a formal sense, but where the reason for the resignation is the conduct of the employer. Where the employer's conduct is sufficently serious as to justify the worker's leaving the employment the resignation will be regarded as a dismissal. In New Zealand the concept of constructive dismissal was in fact accepted as long ago as 197027 but has been developed by the Court since the advent of the personal grievance procedure. The Court of Appeal in Auckland Shop Employees'v Woolworths (NZ) Ltd ${ }^{28}$ has upheld the approach of the Court and the concept must now be regarded as an accepted part of the law.

While the need for such a concept is seemingly self-evident, and was incorporated into the United Kingdom legislation, it has not been accepted in all jurisdictions. In Australia for example the Conciliation and Arbitration Commission seems to have rejected the concept ${ }^{29}$ and it is not recognised in the labour law of the Federal Republic of Germany.

Constructive dismissal can arise in a number of situations. The Court in Auckland Shop Employees' v Woolworths (NZ) Ltd set out three particular situations:

(i) Where the employer offers a choice of resignation or dismissal,

(ii) Where the employer follows a course of conduct with the purpose of compelling a resignation,

(iii) A breach of duty by the employer leads a worker to resign.

Although this area of the law is still expanding it is the factual application of the legal principles in particular cases that can present considerable difficulties. As with any other aspect of justification the degree of misconduct required will be a matter to be determined in the light of the particular circumstances. The Woolworths case was itself a good 
example of how contentious this area can be and of how fine the line may be. The danger is of course that in all but the most obvious cases a worker will "resign" at some risk to their future remedies and a union official advising in such cases is placed in a very difficult position.

\section{Justification}

Central to the application of the personal grievance procedure is the question of whether the particular dismissal or other action is in fact justified; and the Court's interpretation of justification must be one of the central factors in judging the success of the procedure. The Court's approach, while representing a major break from the preexisting common law, could not be described as radical ${ }^{30}$. Its approach reflected developments elsewhere and in particular broad trends in the United Kingdom, whose case law has been the major source of detailed external guidance. However, while this influence has been important in the Court's approach to procedural fairness and constructive dismissal, the Court has warned of the dangers of a close adherence to precedent based on a different legislative and social climate, and uses United Kingdom cases as indicators for its own approach rather than as detailed precedents.

The Court's general approach to unjustified dismissal was explained in $\mathrm{Hepi}^{31}$ where a number of interesting, if rather over-generalised propositions, were made outlining its general philosophy and approach. The Court stated that "The ultimate ... test of justification ... is the opinion of the Court." This opinion, the Court explained, is formed on the basis of a variety of circumstances from the conduct and employment history of the parties through industry custom to ILO standards and social attitudes. The most significant feature of this approach seems to be the strong desire of the Court to avoid firm rules and to retain maximum flexibility, an approach that reflects that adopted in the Court's overall jurisdiction. This approach has resulted in the Court avoiding the stricter approach that seems to have been adopted in the United Kingdom in respect of its test of fairness and its approach to procedural fairness. As noted above, the Court in New Zealand sees the standard of fairness as being its own opinion based on a range of factors and it did not adopt the United Kingdom test of whether the employer acted as a reasonable employer. This is not to argue that the reasonableness of the employer is not an important aspect of New Zealand decisions, but rather that it did not become the overriding test.

At the substantive level it would be difficult to identify any significant difference of approach between New Zealand and the United Kingdom. Workers who are guilty of insubordination, incompetence, habitual absenteism or lateness, misuse of their employer's property and similar offences probably receive no different treatment than elsewhere. Any such difference, if it existed, would be at best marginal.

The most significant development in defining justification has been the Court's approach to procedural fairness. In insisting on the need for faimess in the manner of the dismissal, the Court has placed a strong emphasis on a combination of natural justice and good industrial relations practice. Hopefully this has had the effect of stressing for employers that these two factors are central to proper personnel policies. It is not possible in the time available to go into the details of what constitutes procedural fairness, and indeed in general terms it is self-evident. It includes, for example, warnings of conduct that may justify dismissal, the opportunity to be heard before a dismissal, and a need to follow agreed procedures. 
What is of significance is the Court's position that procedural unfairness alone justifies a finding of unjustified dismissal. This is so even where the worker's conduct would otherwise have justified the dismissal. The Court can of course take the worker's conduct into account when awarding a remedy. The Court's policy in this area again contrasts with what, until recently, has been the United Kingdom approach (Morgan, 1988). The United Kingdom courts have used a test, the so-called "no difference" rule, that subordinated procedural to substantive issues in the finding of faimess. This rule meant that a failure to exercise procedural fairness was only relevant if following the correct procedure would have made a difference to the employer's final decision. The approach in New Zealand ensures that the failure to follow accepted procedural standards will of itself carry some sanction and thus hopefully encourage not only good industrial relations practice but also prevent some grievances from arising.

\section{"Other action.. ..."}

While the unjustified dismissal provisions seem to have posed no major conceptual or legal problems this is not the case with the second leg of the definition of a personal grievance; " other action by the employer affects [the worker's] employment to his disadvantage". The Court's approach to these grievances illustrates the sensitivity of its position and its ability to respond to what it sees as industrial relations realities. The words used in the definition are very general and in principle there seems to be no reason why they could not have been given a generous interpretation. If so a worker would have been given a broad power to challenge an employer's conduct in relation to the particular worker. The Court however adopted a very restrictive approach to this leg of the definition. In the first significant case on the meaning of "other matters" the Court held that the phrase did not encompass a non-promotion case ${ }^{32}$. In later cases a similiarly restrictive approach has been adopted. The general trend of the cases has been that a disadvantage must involve some tangible and demonstrable financial loss. Thus for example, a demotion in status has been held not to fall within the definition as has a disciplinary transfer to a less responsible position or paid suspension ${ }^{33}$.

This category of grievance would seem to illustrate clearly the constraints the Court operated under. The restrictive approach to "disadvantage" contrasts markedly with the broad approach taken to dismissal. The reason for the unwillingness to take a broader approach would seem partly political in that a major involvement in routine personnel decisions may well attract criticism the Court would prefer to avoid, and given the composition of the Court, could cause internal dissension. The Court, in another context, has referred to:
... the lessening need to state our views circumspectly. Principles and their applications do develop case by case. Principles and applications better understood and more accepted by the community can be stated more succintly by the Court. 34

This statement refered to procedural fairness, but it does indicate that the Court moves cautiously in developing the law. The Court's cautious approach would be likely to manifest itself much more in the sensitive areas that a broad interpretation of other disadvantageous action would have opened up. The Court also seems to have preferred to avoid the complexities that such a broader approach might involve. In the Auckland

Auckland Regional Authority Officers Agreement-Application for Interpretation (1974) BA 531.

33 For a discussion of the cases see Hughes, 1986 pp. 59-62.

34 op cit note 20 at p. 672. 
Regional Authority case the Court stressed the problems that would be involved in hearing promotion disputes in a Court setting such as the need to reconsider all applications and to join other applicants to the proceedings. This fear however may have been illusory in such cases if the Court had confined itself to considering the procedural fairness of management decisions.

\section{Remedies}

One major criticisim of the Court has been its approach to the remedies awarded where a finding of unjustified dismissal is made. The Court was able to award any or all of reinstatement, lost wages or compensation, and it interpreted this to include a range of factors that would not have been admissable at common law. These have included expenses incurred because of dismissal together with compensation for humiliation or because of the manner of dismissal. Nevertheless in practice the Court's awards seem subject to two criticisms.

The first is the failure in practice to treat reinstatement as the primary remedy. Although the Court in principle regards reinstatement as the remedy to which first consideration should be given, in practice reinstatement is ordered only in a small minority of cases. This failure may be due to a combination of the "cool realism" of the Court $^{35}$, the lengthy delay between dismissal and a hearing, and the possibility of its perceived disruptive effect especially in small businesses, which are by far the majority in New Zealand. Unfortunately in some cases at least there is the attitude that reinstatement, rather than being a primary remedy, is a reward for "good" employees. In Massof 36 reinstatement was refused to a worker who while efficient, was also a "disruptive and rather argumentative person". The low level of reinstatement does however seem to reflect international trends. In the United Kingdom reinstatement has varied between 3 and 6 percent of successful cases (Dickens et al., 1985, p.109), in the Federal Republic of Germany in 1979 employment continued in 9 percent of cases disposed of by Labour Courts (but in only 1.7 percent by court decision as opposed to agreed settlement) (DosseDigenopoulos and Höland, 1985, pp. 558-559). An exception appears to be the United States where it is the remedy ordered in 40 percent of cases although it seems that only 70 percent of these actually return. (Glasbeek, 1984, p. 141)

There has also been criticism of the Court for the low levels of compensation awarded for lost wages, a criticism that extends into the general enforcement jurisdiction of the Court (e.g. in relation to recovery of underpaid wages). The Federation of Labour has alleged that the Court uses its power to give decisions in "equity and good conscience" to reduce workers entitlements in wage cases and that in the personal grievance area compensation is "token in most cases" (FOL, 1986, pp. 6 and 33). The cases do seem to bear out the general point that compensation rarely covers the full cost to the worker of lost wages and other loss. Some indication of the levels of compensation and remedies awarded by the Court can be gained from the cases reported in 1986.

$\begin{array}{llll}\text { Total cases: } & 51 & & \\ \text { Total number of successful cases: } & 30 & 58 \% \\ \text { Reinstatement ordered: } & 5 & 16 \% \text { of suceessful cases } \\ & 29 & & \\ \begin{array}{l}\text { Total monetary awards: } \\ \text { \$2000 plus }\end{array} & 9 & 31 \% & \text { (Maximum } \$ 6000)\end{array}$




$\begin{array}{llll}\$ 1000-\$ 1999 & 9 & 31 \% & \\ \text { Under } \$ 1000 & 10 & 38 \% & \text { (Minimum \$89) }\end{array}$

The reason for the Court's unwillingness to normally award full compensation can be attributed to several things. The most obvious is the "contributory fault" principle that a worker who has contributed to their own dismissal should receive reduced compensation. Two less tangible rationalisations may also have an effect. The first is that the grievance procedure is not seen as giving any clear legal right to continued employment or to any property rights in a job. The Court seems to regard the personal grievance procedure as a gloss on the strict position in contract. It has stated:

Job protection in New Zealand arises from the recognition of an award employee's right to be treated fairly and does not depend on the specific introduction of an employee's property right in the job ${ }^{37}$.

Combined with this view of the nature of a worker's rights is a concern with the impact of large awards on employers and particularly small employers. The Court has described the majority of employers as

men and women struggling against the odds to make a success of fairly small, and probably undercapitalised, ventures ${ }^{38}$.

The Court's concern to be fair to both sides, together with a view that sees the grievance procedure as aimed at ensuring fairness rather than creating legal rights, seems to have led to a level of compensation that does not recognise the real economic consequences of dismissal. A worker who is found to be unjustifiably dismissed will almost always end up losing. Even in the relatively rare case of reinstatement with full back pay there will be considerable economic and social disruption in the often lengthy intervening period. In most cases the worker will lose their job, regardless of the employer's lack of justification, and will suffer considerable economic loss. The employer on the other hand will escape relatively unscathed regardless of how unjustified their action was. At the worst an employer will be obliged to fulfil their contractual obligations, more usually some lower level of compensation will be required to be paid.

Glasbeek (1984, p. 141) makes the important point that regardless of the eventual decision on justification the employer's cost is offset by:

an unquantifiable but crucial factor, namely, the extra productivity the employer is able to extract from his workforce by the recognition of his ability to exercise (and usual partial subsequent validation of) his right to discipline. The resulting inherent threat of summary discharge with the attendent serious consequences for employees (even if they hope to be reinstated) helps create a compliant workforce. The argument here is that the costs to the employer of wrongful dismissal, while greater than they are at common law, are still not grave enougth to inhibit, seriously, the exercise of his managerial prerogative to fire.

\section{The Green Paper debate}

When the Government issued its Green Paper on industrial relations reforn in 1985 (Department of Labour, 1985), the personal grievance procedure was a well established 
part of New Zealand's industrial relations system and had been tested in practice for over a decade. The Green Paper, the submissions on it and the subsequent submissions on the resulting Bill thus represented a timely review of the procedure and an opportunity to assess its strengths and weaknesses. Such changes as there had been since 1973 were largely minor and had not affected the basic structure of the system.

Perhaps the main point to emerge from the Green Paper debate was the acceptance of the procedure by both employers and unions. This acceptance, while not without reservations, and often serious ones, was a strong indication that the principles at the heart of the personal grievance procedure had become broadly accepted within the industrial relations community. Unlike the concurrent debate in the United Kingdom, for example, there was no major attack on the system itself. Just before the procedure was reviewed in New Zealand the United Kingdom Government had taken a number of steps to limit the effectiveness of their unfair dismissal laws, principally by the imposition of long qualifying periods and by special provisions for smaller employers, steps which together seriously restricted protection for a major section of the vulnerable workforce ${ }^{39}$.

The Summary of Submissions (Department of Labour, 1986) identified three areas of concern among the 64 submissions on the personal grievance procedure. These were:

(a) Access to the procedure. It seems that the majority of submissions favoured an extension of coverage, either to union members in general or to all workers. The Summary mentions that "a few" submissions favoured the introduction of a qualifying period. It is worth noting that in the United Kingdom qualifying periods were used to restrict access to the unfair dismissal protection as these periods have the effect of denying protection to the majority of affected workers. The United Kingdom research indicates that most dismissals tended to occur within the qualifying period 40 . In New Zealand the only real dispute seemed to be whether protection against dismissal should be limited to, and hence a privilege of, union members.

(b) Scope of the procedure. Again the majority of submissions seemed to favour an extension of matters that could constitute a personal grievance, although some employer submissions favoured the status quo. The suggested extensions were of two types;

(i) an extension to cover matters that the Court had held do not constitute a "disadvantage" such as non-promotion, demotion, transfer etc, and;

(ii) an extension to explicitly recognise particular types of grievance as coming within the definition of a personal grievance, in particular sexual harrasment and discrimination.

(c) Procedural suggestions. Procedural problems and delays in the procedure were identified as areas of concern in many submissions. Unions in particular argued that grievance committee chairpersons should be empowered to make a decision, including interim remedies, with the possibility of an appeal to the Court.

39 The British experience including the changes mentioned is discussed in Dickens et al. (1984).

40 Dickens et al (1985) shows that 60 percent of applicants had been employed less than three years and 27 percent less than one year. UK qualifying periods can be up to two years. 
A second area of concern under this heading, and again one particularly identified by unions, was the failure of the existing system to provide adequate remedies. The failure of reinstatement to become the primary remedy was particularly stressed, and it was also argued that the levels of compensation awarded did not recognise the true loss suffered.

The submissions of the two central organisations did not depart significantly from the general tenor of the overall submissions. The Employers' Federation (NZEF, 1986, pp. 63-65), while arguing against any extension of the definition of "disadvantage" had little to say on other aspects of the procedure which they acknowledged as "satisfactory within the constraints of the existing system." At the Bill stage however the Employers' Federation (NZEF, 1987, pp. 56-65) expressed strong opposition to some aspects of the proposed reforms. Strengthening reinstatement as a remedy was described as "doctrinaire" and as "grounded in the idea that employment with a particular employer is a right and property of the worker." The Federation preferred to see the relationship as one "based on trust, which can be irremedially (sic), even though unjustifiably, broken". There was also opposition to extending access to the procedure, although universal access seemed to be considered preferable to access based on union membership.

The Federation of Labour submission (FOL, 1986, pp. 33-34) was somewhat more critical of the existing procedure, although supportive of its basic concept. The Federation's main concern seems to have been to reform the procedure so as to ensure that it delivered effective remedies to workers who had a justified grievance. Their submission thus favoured increasing the practical effectiveness of the grievance committee, which is of course the first formal phase of the procedure. Coupled with this was an emphasis on reinstatement as the prefered remedy.

\section{Conclusion}

The personal grievance procedure as it stood in 1986 can be assessed by three criteria; conformity with the ILO standards, the extent to which it has improved employment security for workers and the extent to which the procedure has prevented or reduced strikes attributable to personal grievances.

\section{ILO standards}

The personal grievance law and procedure as it had developed to 1986 was substantially in line with Convention No 158. The most obvious discrepancy is in the restricted coverage of the procedure. The Convention envisages that all workers should be covered, the only exceptions being mentioned relating to fixed term, casual and probationary contracts $^{41}$. The Convention does not allow for the restrictions imposed in New Zealand. The supplementary recommendation (No 166) does allow the possibility of some exclusions but again only in restricted cases. The two situations mentioned are where special arrangements provide protection that is "at least equivalent", or where "special problems of a substantial nature" arise in relation to the particular employment. The restriction of coverage to union members covered by an award is not within these exceptions. Apart from this major discrepancy the law in New Zealand, including the principles developed by the Court, seems to broadly accord with the standards of the Convention and the Recommendation. 


\section{Enhanced employment security ?}

Given the state of the law before 1973 the personal grievance procedure can not have done anything except enhance employment security. That however tells one little of substance, and the question instead should be whether or not the personal grievance procedure gave an adequate or indeed reasonable degree of employment security. The question can be addressed in two parts; were the law and procedures adequate and did they result in adequate protection in individual cases?

The first question part can broadly be answered in the affirmative. There are defects in the law (especially in its coverage) as outlined above, but generally the law has developed in a liberal manner which has avoided technical restrictions on the ability to pursue a claim and in particular it has placed considerable stress on procedural fairness. The main criticism that could be made is a failure to address the basis of substantive fairness. The Court seems to have proceeded, (and indeed could in practice have done little else) on the basis that the traditional grounds for dismissal continue to provide a justification for dismissal, although this is now tempered by the need to exercise procedural fairness in their application. In doing so the Court has accepted the traditional structure and values of the contract of employment and the rights and obligations implied in it. This contract is one in which the worker is in an inherently subordinate position and in which the terms, and especially those that relate to such amorphous concepts as fidelity and good faith, place employers at a significant advantage when they wish to discipline their workers. The introduction of the idea of contributory fault into personal grievance cases gives a further advantage to the employer in that it allows a degree of legitimacy to be given to almost any dismissal. Significant gains in employment security will require a reappraisal of the employment relationship.

In terms of procedure the main criticism is that of the delays in obtaining the resolution of a grievance. Significant delays impose a considerable burden on the worker, even if an eventual finding is in their favour, and further reduce the likelihood of the primary remedy of reinstatement being granted. This defect is administrative but it does have a significant impact on the procedure's effectiveness and can be exploited as a tactical device.

The second question is whether the law in fact provides adequate security of employment protection in individual cases. This question must be answered in terms of the remedies granted if a grievance is upheld as it is this that is crucial to the position of the individual worker. Success, accompanied by inadequate remedies, is of little consolation to a worker who has lost their job. There has been no detailed study done of the level of awards made by the Court or grievance committees in personal grievance cases and it is therefore difficult to gain an accurate picture of the adequacy of remedies. The inadequacy of remedies, including their failure to reflect the true economic cost to the worker, has however been the major criticism of the procedure made by the union movement.

\section{Strikes}

The figures for strikes attributed to dismissals are set out in the appendix. The most recent figures given differed little fom the 11 percent mentioned by the Minister when introducing the 1970 legislation. The Green Paper concludes that:

The principal thrust of the Industrial Relations Act and its procedures is the provision of quick, accessible and reliable dispute resolution mechanisms in substitution for industrial action. The principle appears to have been frustrated to some degree in regard to the personal grievance procedure. (Department of Labour, 1986, Volume II p. 160) 
It is difficult to disagree with this. While the reasons for unions prefering to rely on strikes are no doubt numerous, their general unhappiness with the effectiveness of the remedies provided and in particular the failure of the procedure to give reinstatement are likely to be in the forefront. Beyond this of course a personal grievance or dismissal may be merely a tangible manifestation of some other problem or issue; an attack on the union by dismissing a delegate or just the result of a general state of industrial disharmony ${ }^{42}$. A personal grievance procedure should not be seen as a panacea and in reality the range of possible disputes and their causes will not always slot into the legal definitions provided.

By the time of the Green Paper review the personal grievance procedure seems to have become an established and relatively non-contentious aspect of New Zealand industrial relations, the basic principles and structure arousing little interest in the submissions. Those parties that made submissions were primarily concerned with different aspects of the effectiveness of the procedure. The extent to which the deficiencies in the procedure and the concerns in the submissions were addressed is examined by Hughes in the following paper.

\section{Appendix}

Dismissals: work stoppages 1971-1984

\begin{tabular}{lcccc} 
& $\begin{array}{c}\text { Number of } \\
\text { Stoppages }\end{array}$ & \% of Total) & $\begin{array}{c}\text { Working } \\
\text { Days Lost }\end{array}$ & (\% of Total) \\
\hline 1971 & 21 & $(6.7 \%)$ & 13775 & $(8.5 \%)$ \\
1972 & 38 & $(13.4 \%)$ & 19434 & $(13.8 \%)$ \\
1973 & 42 & $(10.7 \%)$ & 14393 & $(5.3 \%)$ \\
1974 & 24 & $(6.3 \%)$ & 12016 & $(6.5 \% 0$ \\
1975 & 46 & $(10.8 \%)$ & 22254 & $(10.4 \%)$ \\
1976 & 26 & $(5.3 \%)$ & 10919 & $(5.4 \%)$ \\
1977 & 45 & $(8.0 \%)$ & 13841 & $(3.2 \%)$ \\
1978 & 29 & $(7.1 \%)$ & 7675 & $(2.0 \%)$ \\
1979 & 26 & $(5.0 \%)$ & 8525 & $(2.2 \%)$ \\
1980 & 28 & $(8.0 \%)$ & 22093 & $(6.1 \%)$ \\
1981 & 42 & $(14.4 \%)$ & 39155 & $(10.1 \%)$ \\
1982 & 39 & $(11.7 \%)$ & 16677 & $(5.1 \%)$ \\
1983 & 35 & $(10.5 \%)$ & 20027 & $(5.2 \%)$ \\
1984 & 38 & $(10.4 \%)$ & 37041 & $(8.7 \%)$ \\
\hline
\end{tabular}

Source: Department of Labour, 1985, Volume II, p.160

\section{Bibliography}

Anderson G J (1978) Procedures to settle personal grievances: an examination of section 117 of the Industrial Relations Act 1973 Industrial Relations Centre, Victoria University.

Anderson G J (1982) Limits on the right to claim for unjustified dismissal New Zealand -law journal : 59-64.

Department of Labour (1985) Industrial relations; a framework for review 2 volumes, Wellington, Government Printer. 
Department of Labour (1986) Industrial relations; a framework for review -summary of submissions Wellington, Government Printer.

Dickens L et al. (1984) The British experience under a statute prohibiting unfair dismissal Industrial and labor relations review 37: 497-514.

Dickens L et al. (1985) Dismissed: A study of unfair dismissal and the Industrial Tribunal system Oxford, Basil Blackwell.

Döse-Digenopoulos A and Höland A (1985) Dismissal of employees in the Federal Republic of Germany The modern law review 48: 539-563.

FOL (1986) Looking ahead: a more just industrial relations system. NZ FOL viewpoint on industrial relations reform Wellington, New Zealand Federation of Labour.

Glasbeek H J (1984) The utility of model building-Collins' capitalist discipline and corporatist law The industrial law journal 13: 133-152.

Green R L (1966) Procedures to settle disputes over alleged wrongful dismissal Industrial Relations Centre, Victoria University.

Howells J M and Cathro S H (1986) Mediation in New Zealand: the attitudes of the mediated Palmerston North, Dunmore Press.

Hughes J (1986) Dismissal disputes; law, practice and procedure Christchurch, Christchurch Polytech.

ILO (1983) Record of proceedings of the 68th session, Geneva 1982 Geneva, ILO.

Long-Term Reform Committee (1983) A description of wage fixing and industrial relations in the private sector Wellington, Government Printer.

Morgan J (1988) 'No difference' for dismissal ? Solicitors journal 132 (8): 242-244.

NZEF (1986) The industrial relations Green Paper; an employer perspective Wellington, New Zealand employers federation.

NZEF (1987) Submissions to the Labour Select Committee on Labour Relations Bill 1987 Wellington, New Zealand employers federation.

Szakats A (1988) Introduction to the law of employment 3rd edition, Wellington, Butterworths. 
The Journal of the Industrial Relations Society of Australia

Editor: Professor John Niland, The University of New South Wales

September 1988 - Volume 30 Number 3

\section{Articles}

Rethinking Occupational Health and Safety Legislation

Adrian Brooks

Natural Attrition: The Preferred Option?

Kathy Turner

Employment and Wages Policy in Papua New Guinea

John Lodewijks

Labour Flexibility Strategies and Management Style

Bob Horstman

Technological Change and the Future of Work Belinda Probert and Judy Wajcman

The 'Closed Shop' and Equal Opportunity:

Hein v. Jaques Limited

Richard Johnstone

Book reviews

Published quarterly. Subscription: Australia $\$ 32$, overseas $\$ A 45$ (surface mail).

Single issues: $\$ A 9$ (including postage). Order from the

Business Manager, The Journal of Industrial Relations,

GPO Box 4479, Sydney, NSW 2001, Australia. 